\title{
AN OVERVIEW OF THE TRUDEAU CONSTITUTIONAL PROPOSALS
}

\author{
RICHARD SIMEON*
}

The Trudeau Resolution, defining the process by which the federal government hopes to achieve constitutional reform, has been the source of much conflict between the federal and provincial governments. While supporting some elements of the Resolution, the author criticizes many others and points out what he considers to be the fatal flaw in the resulting model of Canadian federalism: its dependence on the ability of the federal government to represent and be seen to fairly represent all Canadians. Possible long-term effects of the Resolution on Canadian federalism and the necessity of reconciling the provincial and federal viewpoints are also examined.

Talking about the Constitutional debate is like shooting at a moving target: any comment is likely to be outdated almost as soon as it is written. This paper, therefore, should be used as one person's comment on events as they looked in February, on the eve of Parliamentary debate on the federal constitutional initiative. Whatever its fate the broader issues of the Confederation debate will remain with us.

I want to look at the Resolution concerning a Joint Address to the Queen Respecting the Constitution of Canada in terms of some questions about the future of Canadian federalism. What kinds of answers does it give to the fundamental tensions which have increasingly divided Canadians, and which generated the constitutional debate in the first place? Does it offer a way out of what Don Smiley' calls the "compounded crisis" of Canadian federalism - or is it, as I fear, just another element in that crisis, deepening, rather than resolving, the tensions between government and government, region and country, east and west, French and English?

At the outset, I should say I support a great deal that is in the Resolution even though I believe that the whole is deeply flawed. First, it calls for patriation of the constitution, ending the ludicrous remnant of colonialism which keeps our basic law an Act of a foreign Parliament. That is obviously desirable, though not, I think, worthy of Professor LaForest's ${ }^{2}$ comment 'I want it so badly, I could eat it".

Second, the reason we did not patriate many years ago, of course, is that we could not, then or now, agree on a method to amend the B.N.A. Act once we did get it back. The Resolution provides two methods of amendment - both highly controversial.

The first is the familiar "Victoria formula" by which an amendment requires consent of the federal Parliament, together with the legislatures of Ontario and Quebec, two of the Atlantic provinces, and two western provinces with at least half of the population of the region. This formula had virtually unanimous support when first proposed in 1971; since then it has been attacked because of the permanent veto it gives to two provinces and for its failure to treat all provinces equally. Much more controversial is a

- Director, Institute of Intergovernmental Relations, Queen's University.

1. Donald V. Smiley, Professor, Dept. of Political Science, York University.

2. Gerard LaForest, Professor, University of Ottawa (Common Law), appointed to the Court of Appeal of New Brunswick effective Sept. 1, 1981. 
referendum device, by which, if Ottawa wishes an amendment, but cannot win sufficient provincial consent, then Ottawa may call a referendum to break the deadlock. In this case a majority of the voters, in sufficient provinces to meet the Victoria criterion, would suffice. This has been attacked as a violation of the spirit of federalism: the federal government would decide when there was a deadlock, and would define the question which would be put to the people over the legislatures' heads. No reciprocal right for the provinces to call a referendum when Ottawa stood alone would be granted.

Third, the Resolution contains a detailed Charter of Human Rights and a more limited set of minority language rights. The Charter significantly reduces the powers of the provincial governments, and has been bitterly opposed by most of them. I recognize that there is a strong, principled argument against entrenchment of rights - an argument related to the greatly increased role that it gives to the courts, as distinct from elected legislatures, and to the many legal uncertainties it will create for years to come - but on balance, I now support entrenchment. Indeed I believe that the Charter is much improved after some of the loopholes in the original proposals have been closed as a result of representations at the Joint Committee. But these virtues in the Resolution are fatally tainted: the costs of the federal action greatly outweigh the benefits a Charter will bring us.

The Resolution also includes a provision for entrenching equalization, and a limited guarantee of provincial rights in natural resources.

I have three kinds of objections to the Resolution. First and foremost I am concerned about the procedure being used; that is, the assertion by the federal government that it can and should act unilaterally, without provincial support, to amend the constitution which, after all, governs the relations between both orders of government. How we get a new constitution is as important as what it actually contains. Its legitimacy depends on the degree of consent it can command. The Resolution, opposed by most provinces, and apparently by a majority of public opinion, lacks sufficient consent. It splits and divides us more than it unites. Moreover, the methods and spirit of achieving change can become a precedent, a template for the future. I would not want this Resolution to be our model. It embodies a conception of federalism I do not accept, and is, I think, quite unconstitutional, whatever its purely legal status.

The justifications for acting unilaterally are not very persuasive. It is a little specious to argue that unilateral action is essential because after 53 years of trying, we can wait no longer. That implies we have been constitutionally paralyzed for all that time. In fact, the current round of constitutionmaking really began only quite recently - one can date it from the fall of 1978 , or the election of the P.Q. in Quebec in 1976, perhaps even from the Confederation of Tomorrow Conference in 1967. But the urgency, and the global concern with it, is recent.

Nor is the "trap of unanimity" as Mr. Trudeau calls it the reason for failure this time, although it was in 1971. This time the opposition is not from one, but from the great majority of provinces. Progress is not blocked by one or two recalcitrant premiers.

Nor is the necessity of redeeming the promise made to the Québècois in the referendum campaign sufficient justification to overturn custom and convention, or for example, suddenly to introduce a referendum procedure into constitutional amendment, even though it had never before been discussed 
at a federal-provincial conference or in the country generally. Indeed the promise was made and must be redeemed - but what was the promise and what was the expected response? The fact that no political leaders in Quebec not linked to Ottawa have supported the Resolution, suggests that this argument is not sufficient. I doubt this is the "renewed federalism" the Québeccois felt they would get if they voted "No" to the referendum.

We see the federal government seeking to achieve in Britain what it cannot achieve at home. There is a fine irony here: it is the very characteristic of our present constitution which Ottawa feels is so unconscionable which permits it to do what it is doing. For the government cannot win sufficient consent in Canada according to any of the formulae for amendment which have previously been proposed; nor can it even win consent by the very amendment procedure contained in the Resolution. Instead, it must by-pass the domestic process and ask Britain if we can be a colony one more time, asking Britain to change it before sending it back. I find it very strange that an action specifically prohibited by Section $91(1)$ of the B.N.A. Act should be made by going to the U.K.

I am also very concerned at the danger that difficulties in Britain will now be defined as an issue of British colonialism, of "The Empire Strikes Back". In fact the problem in Britain is entirely of our own making. We place Britain in the position of having to take sides, of meddling whatever it does. We explicitly asked Britain to retain control over the B.N.A. Act in 1931 because we could not agree among ourselves, and because we did not want to give Ottawa the unilateral power to amend it.

So, the procedure is seriously flawed.

Second, I do not support some important elements of the content of the Resolution. Here the amendment procedure raises the greatest difficulties.

But third, I think we should be as concerned with theincompleteness of the Resolution - what it leaves out - as much as with what is in it. It does nothing to strengthen the federal government's legitimacy or base of support; it ignores entirely the provincial constitutional agenda. It does not address the division of powers and responsibilities between governments; it does not include proposals for strengthening the machinery of federalprovincial cooperation, all of which are essential to any overall settlement.

Three great challenges gave rise to the constitutional crisis we have been living through. First, the relations between the two great language groups in Canada, in which many Québècois' views of Quebec as the homeland of a distinct national community clashed with the vision of a Canada in which French and English-speaking Canadians could feel at home anywhere. That debate remains unresolved inside and outside Quebec.

The second problem concerns the relations between provincial and Canada-wide communities, in which a growing provincialist conception confronts a desire to reverse the trend and reassert national dominance. The third involves the relations between governments, where the issues are not only federal power versus provincial power, but the collective ability of all eleven governments to generate effective policy and serve the interests of citizens, interests which are by no means always defined in regional or territorial terms.

Constitutional proposals must be tested against the question: do they respond to these challenges? Do they promise a better way of meeting them in 
the future? I am afraid that the present Resolution at best provides incomplete and partial answers; and at worst makes them even more difficult to deal with in the future. Even if passed, it leaves many pressing constitutional questions unresolved and it creates a poisoned atmosphere which makes it unlikely they can be addressed in the near future. In the name of a partial solution, it forecloses the possibility of future progress.

Those are the obvious criticisms. Let us stand back a bit though and see how we got here. Let us look at the competing views underlying the federal proposals on one hand, and the views of its opponents on the other. For there are big choices to be made. At one level, as Alan Cairns ${ }^{3}$ insists, this may be nothing more than an unseemly struggle for power between rival politicians, or no more than a grubby struggle over dollars. But it is much more than that. At stake also are some very basic conceptions of the character of the Canadian community: about the ways those communities will be expressed and represented politically; about the role we expect federal and provincial governments to play; and about our ability to work out acceptable accommodations between competing regional interests. It is not enough to call $\mathrm{Mr}$. Trudeau a usurper, or the premiers nothing more than feudal barons or "Chinese warlords".

My colleague Ed Black4 describes Ottawa's action as a "constitutional coup $d$ 'état". That may be a bit strong, but the Resolution is an act worthy of a nation-builder like de Gaulle or Bismark; a decisive attempt to sweep aside the restraints of archaic procedures and vested interests. Mr. Trudeau wished to break the deadlock, cut the Gordian knot and challenge a concept of federalism which he felt could only lead to national paralysis and fragmentation. He also believed that, with a majority in Parliament, and a victory in the Quebec referendum, he now had the political power to do it. He believed he had shown the premiers to be narrow, parochial and self-serving at the September First Ministers' Conference, and that his "package for the people" - patriation and rights - had popular support. Politically this was the moment.

At that Conference, held in the marvelously appropriate setting of an old railway station, we saw expressed more explicitly, more clearly than ever before, two visions of Canadian federalism - and once more the inability to find a way to reconcile them. The confrontation between the two images is what has underlain the whole constitutional debate. Each concept has powerful defenders in the federal and provincial governments. The dilemma has always been that each has been too weak to prevail; but each has also been too powerful to be defeated. It was this impasse which $\mathrm{Mr}$. Trudeau felt he now could break.

There is a nice paradox here: the whole constitutional debate originated in the pressure first by Quebec, but then later by other provinces, for greater powers and a greater voice in national decision-making. Ottawa had been on the defensive. But by the summer of 1980 , it felt that the tide was running in its favour: concessions offered to the provinces - such as on natural resources - were now withdrawn. New issues - notably so-called "powers

3. Alan C. Cairns, Professor of Political Science, University of British Columbia, and author of the commentary immediately following this article.

4. Edward Black, Professor of Political Science, Queens University. 
over the economy" - were pushed hard. That meant that the "package deal" which would require considerable federal concessions to the provinces in some areas and parallel concessions by the provinces was no longer possible. Rights would not be traded for fish; a package for "people" could not be compromised by a grubby search for power. We will probably never know precisely who was to "blame" for the failure to agree in September. But there had been real progress over the summer; a deal did seem to be in reach. And I believe it need not have failed.

Defenders of each model saw the other as a radical attack on "true" Canadian federalism. The Resolution, said Mr. Blakeney, "is constitutionally wrong; it is not federalism". But Mr. Trudeau replied that Mr. Blakeney's view might be "the essence of a federal state, but it has not been the essence of the Canadian federal state". Essences, history and legal precedent do not help us much. What are these competing views?

Mr. Trudeau, oddly enough, is the Sir John A. Macdonald in the current debate. His is what we might call the Ottawa-centered view. That is what animates the Resolution. Its first assumption is that, whatever our regional, ethnic and social diversity the first, the primary community to which Canadians belong is the country as a whole. It is on the broad national stage, from sea to sea, that citizens can maximize their freedom and opportunity. They must share a commitment to that wider community; and they share common, universal rights by virtue of their membership in it. Indeed such rights can be, as Alan Cairns has pointed out, a major focus for national loyalty. Hence the profound importance of the Charter of Rights and patriation in the Resolution, priorities which Mr. Trudeau has asserted since first coming to Ottawa in 1968. Along with this is a conception of the "national interest" or the "common good". It is very much more than the sum of regional or provincial interests; it transcends region. It is rooted in individuals, not in provincial communities: national majorities - not provincial ones - are what count. Given a conflict between national and provincial interests, the former must prevail.

A number of important consequences flow from this perspective. Economically, it stresses the need for a true common market in Canada, and attacks the growth of provincially-inspired internal barriers to trade, which are felt to be leading to balkanization and fragmentation. Hence the emphasis on freedom of movement of people and capital, and the desire to strengthen section $121^{5}$, and the federal trade and commerce and power. Ottawa must be responsible for overall economic management, and for redistributing wealth across the country. Resources are a national, not just a provincial asset, to be shared by the national government.

This impulse also asserts itself in other areas - socially, in emphasis on national "standards", culturally, in support for the CBC and other such institutions. It argues that French and English-speaking Canadians must have rights throughout the country, and rejects the concept of two geographically separated linguistic communities, which inspired Quebec's Bill 101.

But it is the political implications which concern us most. The primacy of the national community implies equally the primacy of the federal govern-

5. "All Articles of the Growth, Produce, or Manufacture of any one of the Provinces shall ... be admitted free into each of the other Provinces." 
ment, the only institution which represents the whole community. Mr. Trudeau has stated:

We here in Parliament are the only group of men and women in this country who can speak for every Canadian. We are the only group, the only assembly which can speak for the whole nation, which can express the national will and the national interest.

This view is tied, in turn, to the doctrine of parliamentary supremacy. "When Parliament is not supreme, the very basis of responsible government begins to crumble." But what of a federal system, where there are provincial parliaments too? Mr. Trudeau rejects bargaining between them and Ottawa as the way to determine the national interest, since that is unparliamentary and makes the real sovereign the intergovernmental bargainers. Where there is fundamental disagreement, conflicts over power, he argues, then some government - and it can only be the federal Parliament - must be fully accountable.

From this it follows that the overriding or discretionary powers given to the federal government, which allow it to act in areas of provincial responsibility - the spending power, the declaratory power, the emergency power must be retained, and not subject to provincial veto. The federal Parliament is supreme. That doctrine, of course, also provides the justification for Parliament acting unilaterally on the constitution. And it justifies Parliament's being able to call a referendum to secure popular consent for a future amendment if the federal government cannot secure the agreement of the provinces. Ottawa decides when there is deadlock and phrases the question; provinces cannot initiate a referendum.

In this Ottawa-centered view, Canada is not a collection of provincial communities. Nor are provincial governments the chief representatives of their populations - federal Members of Parliament are too. Hence, there is reluctance to accept any provincial demands for greater power, or to give provinces a greater role in making national policies. Ottawa speaks for Canada - not the federal-provincial conference of first ministers. It is also argued that the trend towards decentralization in Canada must be reversed; we are already, it is repeated endlessly, the most decentralized federation in the world; any more and we become "ten principalities", hopelessly balkanized.

This view runs through the federal Resolution, and this is what makes it so repugnant to the provinces. Yet, the government was not Gaullist enough to push as far as it might have. In deference to Ontario, the government did not push language rights nearly as far as it should have. The Charter of Rights will limit provincial power, but does not add directly to federal powers. Ottawa drew back on powers over the economy.

There is a compelling logic to this view. Even here in Edmonton I am sure there are many who support it. It has powerful support in history: this was Sir John A. Macdonald's image of Confederation, and the B.N.A. Act as written does indeed place provinces in a subordinate, almost colonial, position with relation to Ottawa. There is a great deal in it I support.

But there are serious problems with the model in contemporary Canada. For many reasons - the trend of judicial decisions, the growth in importance of areas in provincial jurisdiction, the inability or unwillingness of Ottawa to act decisively to maintain Canadian independence or to promote economic integration within Canada - Canadian federalism has moved in a different direction. Provinces have become more powerful, control a greater share of the public purse, are more central in the lives of their citizens, are more 
credible as spokesmen for regional interests than $\mathrm{Sir}$ John A. Macdonald would have expected. Central dominance as reflected by the Ottawacentered model no longer seems realistic, however much we lament its passing.

More important, there is a fatal flaw in the model. It depends, fundamentally, on the ability of the national government to be able to represent and speak for the whole country, to be the arena where diverse regional interests can be accommodated. It depends on the belief by citizens everywhere that it is fair, and responsive. It depends on the ability of federal politicians and federal institutions to work out accommodations between divergent regional interests. Our federal leaders and institutions can no longer do that. Partly that is because of simple population and numbers. Under the principle of majority rule, Ontario and Quebec will always outvote the West.

But this is powerfully reinforced by the failure of the national party system: we have no national parties. Whichever party is in power in Ottawa, some part of the country is frozen out of representation in the governing caucus and cabinet. And in the British parliamentary system the cabinet is all-important. Surely this is a powerful source of western alienation. This is what makes it credible when Mr. Lougheed says "I speak for Alberta". And this is what makes it seem that the "national interest" is little more than the Ontario regional interest.

Indeed, Mr. Trudeau has suggested that parliamentary government and federalism may be deeply in contradiction with each other. Federal cabinets do not adequately reflect our regional diversity; party discipline denies the Opposition any real influence and prevents cross-party regional alliances. The need to manage massive departments leaves Ministers little opportunity to act as regional spokesmen. And, parliamentary government is predicated above all on the idea of majority rule: there are few limits on the power of the cabinet. It is not at all clear that a country like Canada can survive unrestricted majority rule or what Don Smiley calls "federal majoritarianism".

Unfortunately the Resolution gives no recognition of this fatal flaw. It seems to me that the central concern of advocates of this model must be to explore ways to overcome it, to make Ottawa more truly effective and representative. Various means have been proposed - such as some form of proportional representation - to ensure each major party at least some representation from all regions, or an elected Senate. Perhaps we need even to rethink our commitment to a parliamentary system itself. A national government must be national; it must have the political support and legitimacy to exercise the power claimed for it. That is not the case today.

What about the other side - the alternative, province-centered image of Canada? At its most extreme, it asserts a truly Confederal view: that Canada is a compact, an alliance, between provinces; that Ottawa exists on their sufferance, its powers determined by them. Few in Canada today argue this position unequivocally, and its historical validity is highly questionable, but it is reflected in many provincial arguments.

First, the provincial community is at least as important as the national community. Provincial rights cannot simply be overridden by national majorities. Provinces are felt to be closer to the people, more responsive, better able to act in pursuit of regional interests. In particular, federal policy is felt to be often unfair, discriminatory, incompetent. It almost seems as if Confederation is not a positive-sum game, or even a zero-sum game; listening to the complaints, it seems as if everyone loses. 
In this view, not only is the national interest not necessarily superior to the provincial interest, but also Ottawa is not the sole spokesman for the national interest. That emerges too from the interaction of provinces and the federal government. "But who will speak for Canada?" asked Mr. Trudeau at one conference. "We all do," replied Mr. Lougheed.

Again, a number of consequences flow from this position. Economically, provinces must be free to control their own resources and manage their own economic development. They should be able to plan their own social, cultural and linguistic policies. Constitutionally, it means that provinces should have more powers in certain areas - resources, communications and so on. It means that the broad federal discretionary powers to act in areas of provincial jurisdiction - intrusions - should be limited, subject to provincial approval. It means provinces should be given a greater say and influence in federal policies which affect them. It means an amendment formula which rests on the consent of legislatures, and requires a high level of agreement, if not total unanimity, so that no province's vital interest can be overridden by the national majority. Majority rule is tempered by the equality of all provinces. All that necessarily implies an even greater role than at present for federal-provincial conferences as national policy-making bodies.

All of these issues have been prominent on the constitutional agenda in recent years. All of them are of course entirely missing from the federal Resolution. We were faced with two quite different models for change: only one has been acted on.

There are of course many serious criticisms to be made of this second model too. Some see it as leading to a narrow parochialism, to an even more fragmented economy, to destructive competitive bidding among provinces for industry and investment, to a situation in which the strong thrive, and the weak fall further behind.

Taken to its extreme, one model does imply little more than ten independent states; the other implies a unitary state. Moreover, each, at the extreme, dispenses with the idea of the equality of governments in a federal state and with any clear division of powers between them - since each lays claim to virtually all the levers of governing.

My own view is that neither model can or should prevail to the exclusion of the other. Each model is compelling; each has widespread support. The Resolution artificially forecloses a debate which has a long way to go, which is indeed woven through all Canadian history. Canadians are being forced to make a choice which I do not think they are ready to make. They are asked to accept a constitutional package which does not in any way resolve the conflict. I think the surveys show clearly that Canadians do not want to choose; that they really are good federalists. This explains the polls which show very large majorities for much of the content of the Resolution, but at the same time equally large majorities against the way it is being done. Dual loyalties are not seen by most people as incompatible; the images are not seen as mutually exclusive, but as complementary. And if we do not see them that way, then prospects for accommodation are dim. I doubt that the polarization we see now between governments is shared by most citizens.

That, then, defines the constitutional challenge. It is not to impose one or other of these two models. It is to build a framework within which a permanent dialogue can go on, one which reconciles the two models, one which offers something for both, one which maximizes the incentives for compromise and accommodation. 
I do not think that is impossible. Pepin-Robarts, Claude Ryan, and others have all pointed the way. It means that we must respond to several items on the provincial agenda during last summer - in areas like control of natural resources. We should also remove from the constitution obsolete powers of federal dominance like disallowance and the declaratory power. Other powers which permit Ottawa to intervene in areas of provincial jurisdiction should be subject to provincial consent before they are used. There should be no subordinate, junior governments, no superior dominant one.

However, we must also respond to the federal agenda. Most important here is the Charter of Rights. If the joint Parliamentary committee on the Constitution has shown anything, it has shown that there exists a constituency for that which will not be denied. We must also give much greater attention to the whole question of economic powers, especially the preservation of the common market.

Similarly, even while confirming and perhaps strengthening provincial powers in some areas, we must at the same time be thinking of ways to restore national support and legitimacy to the central government. So it is not a matter of either strengthening the provinces or strengthening Ottawa; it is rather a matter of doing both, messy and awkward as that might be.

Finally, we must strengthen what could be called the institutions of federalism itself; those which maintain the "federal bargain", which govern the relationship between the different levels, and which provide the framework for cooperation. Here I am thinking of the need for agreement on an amending formula and the need for constitutional entrenchment of the Supreme Court, with a provincial role in appointing the judges especially important if we have a Charter of Rights. Most important, we need to go beyond the present federal-provincial conference to establish something like a federalprovincial council at which the two levels can come together to cooperate in policy-making. My assumption here is that if we are to govern Canada effectively at all, we have to govern it as a partnership. Virtually all of our major problems cut across jurisdictional lines: Ottawa needs provincial cooperation and vice versa: each has the power to block and frustrate the other - not to mention the rest of us. So we need better machinery for cooperation - which will ensure greater sensitivity to regional interests in Ottawa; and greater sensitivity to national needs in the provinces. That is essential if, for example, we are even to have a national industrial strategy.

None of this, of course, is a panacea - it is a delusion to think that any constitutional tinkering would be. There is no magic wand, no Holy Grail of a new constitution waiting to be found. Any settlement, in order to work, must be backed by trust and goodwill - a commodity in very short supply in the hostile atmosphere generated by the constitutional issue, energy and others. Thus, even more broadly, we must also be thinking in non-constitutional terms for ways to strengthen the positive, mutually beneficial linkages in the country: I am thinking here of economic linkages of all kinds, of associations, interest groups, political parties. The burden of national integration cannot be left to the intergovernmental bargaining process alone. The cement is being chipped away today; we must be mixing more mortar. The constitution is only one of the ingredients.

All of this is set back, not advanced, by the current constitutional battle. So what do we do now? We must first find a face-saving way out of this damaging, destructive confrontation - then find a more promising framework for renewed discussions. 
I believe strongly that no more should be demanded of Britain than patriation and the existing amending rule. We must resolve the issue, not in Britain, but here at home. I believe that, in any case, no request should go to Britain before the matter has been finally resolved in the Canadian courts. If the Charter stays in the Resolution, it should at first be binding only on Ottawa, with a provision for provinces to opt in - and I believe that public pressure would soon lead to their doing so.

Finally, it will eventually be necessary to pick up the pieces from the end of last summer and to get back to the federal-provincial bargaining table. Constitution-making by federal-provincial conference has a great many weaknesses. The incentives to compromise are just not strong enough. It focuses almost entirely on regional issues. Many citizens have recently sought alternatives - most dramatically some have proposed to put the governments aside entirely and to convene a constituent assembly of some sort. It is an attractive idea, but I doubt that it is either possible or desirable.

However, I do think that the Joint Committee has shown the size of the constituency which wants to make its voice heard on constitutional issues. It has changed the politics of constitution-making. Once the governments get together again, there will have to be recognition of this new dimension. It will have to give a greater role to non-governmental interests. Why, for example, should there not be a joint federal-provincial committee - perhaps even several - which would hold public hearings and feed their findings into the First Ministers' Conference? There are many possibilities, and I think we should be exploring them.

We now exist in a constitutional limbo. The existing constitutional order has lost its legitimacy. The federal Resolution is fatally flawed. It is not easy to see how to restore the kind of trust which alone will allow us to succeed, which is more than exhortation. But it is essential that we do achieve that trust. 